\title{
Erythroderma secondary to crusted scabies
}

\author{
Gurumayum Chitralekha Devi (ㄷ), Neirita Hazarika
}

Department of Dermatology, Venereology \& Leprsoy, All India Institute of Medical Sciences, Rishikesh, Rishikesh, Uttarakhand, India

\section{Correspondence to} Dr Neirita Hazarika; neirita.derma@aiimsrishikesh. edu.in

Accepted 23 November 2021

Check for updates

(c) BMJ Publishing Group Limited 2021. No commercial re-use. See rights and permissions. Published by BMJ.

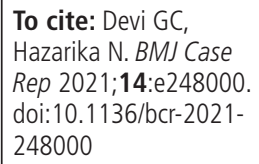

\section{DESCRIPTION}

A man aged 45 years with known case of psoriasis on remission presented with generalised erythema and scaling for 1 month. History of self-prescribed steroid, antibiotics, topical salicylic acid formulations led to only temporary relief. On examination, diffuse, hyperkeratotic, yellow scales were noted on an erythematous base, covering 95\% body surface area (BSA) (figure 1). A provisional diagnosis of psoriatic erythroderma was made. During workup, $10 \%$ potassium hydroxide $(\mathrm{KOH})$ mount of scales revealed 5-6 scabies mites/high power field (figure 2). Serum cortisol level at 08:00 hours was $0.3 \mu \mathrm{g} / \mathrm{dL}$ (normal: $5-23 \mu \mathrm{g} / \mathrm{dL}$ ). Other investigations (complete haemogram, liver function test, kidney function test, random blood sugar, glycosylated haemoglobin, viral markers, urine routine microscopy, chest X-ray and ECG) were normal. Diagnosis of erythroderma secondary to crusted scabies with iatrogenic Cushing's disease (due to self-prescribed steroid) was made. Patient was put on oral ivermectin $(200 \mu \mathrm{g} / \mathrm{kg})$ on days $1,2,8,9$ and 15 , and $5 \%$ permethrin cream daily for 7 days then twice weekly until no mite was detected on $\mathrm{KOH}$ mount. The hyperkeratotic plaques cleared by 3 weeks. For iatrogenic Cushing's disease, physiological doses of tablet prednisolone $5 \mathrm{mg}$ in morning and $2.5 \mathrm{mg}$ in evening were started as advised by endocrinologist and the patient was followed up in endocrinology OPD.

Crusted scabies is a hyperinfestation state, caused by mite Sarcoptes scabiei var. hominis, with millions of mites and hyperkeratotic skin lesions. A $\mathrm{T}$ helper 2 response, selective movement of $\mathrm{CD} 8+$ $\mathrm{T}$ cells, minimal helper $\mathrm{T}$ lymphocytes $(\mathrm{CD} 4+)$ and absence of $\mathrm{B}$ cells in dermis, contribute to the uncontrolled growth of the mite. ${ }^{1}$ Activated $\mathrm{CD} 8+\mathrm{T}$ cells induce dysregulated keratinocyte

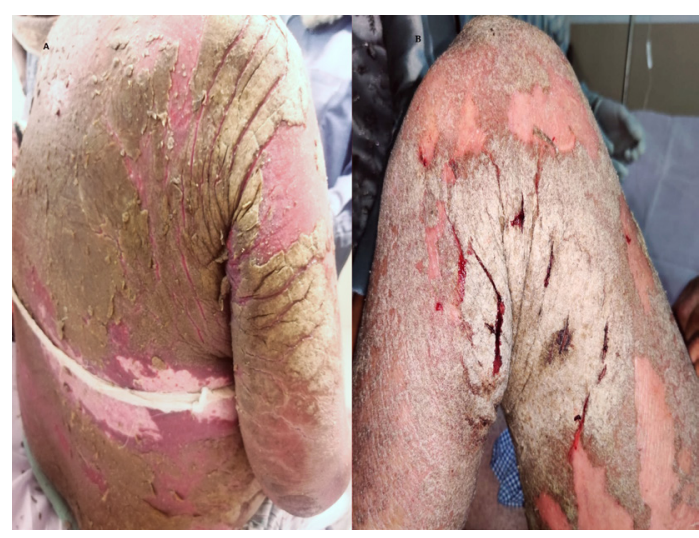

Figure 1 (A and B) Diffuse, hyperkeratotic scales, fissures with bleeding and erosion on an erythematous base, present over trunk and lower limb.

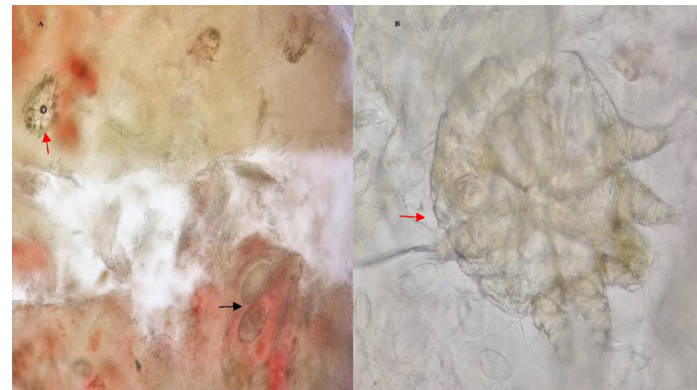

Figure 2 (A and B) Microscopy of mineral oil preparation of scales obtained by scraping revealed mites of Sarcoptes scabiei var. hominis (red arrow) and eggs (black arrow).

apoptosis contributing to epidermal hyperproliferation. Crusted scabies has been reported with immunosuppression, HIV, leprosy, tuberculosis, substance abuse, systemic lupus erythematosus, diabetes mellitus, hepatitis, neurological diseases causing reduced sensation, immobility states causing reduced scratching, in genetically susceptible patients and also in people with no susceptible factor. ${ }^{1} \mathrm{~A}$ bedside $\mathrm{KOH}$ mount can easily establish the diagnosis of crusted scabies.

\section{Learning points}

- Crusted scabies is characterised by generalised itchy, hyperkeratotic yellowish scales.

- It can sometimes be mistaken for erythrodermic psoriasis.

- A bedside potassium hydroxide mount can easily establish the diagnosis of crusted scabies.

Contributors NK contributed to patient management, planning and writing paper and GCD contributed to patient management and consent taking and writing paper.

Funding The authors have not declared a specific grant for this research from any funding agency in the public, commercial or not-for-profit sectors.

Competing interests None declared.

Patient consent for publication Consent obtained directly from patient(s).

Provenance and peer review Not commissioned; externally peer reviewed.

Case reports provide a valuable learning resource for the scientific community and can indicate areas of interest for future research. They should not be used in isolation to guide treatment choices or public health policy.

\section{ORCID iDs}

Gurumayum Chitralekha Devi http://orcid.org/0000-0002-68444084

Neirita Hazarika http://orcid.org/0000-0003-4768-2857 


\section{Images in...}

\section{REFERENCE}

Copyright 2021 BMJ Publishing Group. All rights reserved. For permission to reuse any of this content visit https://www.bmj.com/company/products-services/rights-and-licensing/permissions/

BMJ Case Report Fellows may re-use this article for personal use and teaching without any further permission.

Become a Fellow of BMJ Case Reports today and you can:

- Submit as many cases as you like

Enjoy fast sympathetic peer review and rapid publication of accepted articles

Access all the published articles

Re-use any of the published material for personal use and teaching without further permission

\section{Customer Service}

If you have any further queries about your subscription, please contact our customer services team on +44 (0) 2071111105 or via email at support@bmj.com.

Visit casereports.bmj.com for more articles like this and to become a Fellow 